\title{
The Cell Block Method Increases the Diagnostic Yield in Exudative Pleural Effusions Accompanying Lung Cancer
}

\author{
Hücre Bloğu Yöntemi Akciğer Kanserine Eşlik Eden Eksudatif Plevral \\ Sıvılarda Tanıyı Artırmaktadır
}

\author{
Deniz KÖKSAL' ${ }^{\text {, Funda DEMIRAĞ² }}$, Hülya BAYiZ , Adem KOYUNCU', Neslihan MUTLUAY', \\ Bahadır BERKTAŞ ${ }^{\prime}$, Mine BERKOĞLU'
}

Department of ${ }^{1}$ Chest Diseases and ${ }^{2}$ Pathology, Atatürk Chest Diseases and Chest Surgery Training and Research Hospital, ANKARA, TURKEY, ${ }^{3}$ Department of Chest Diseases, İstanbul Gebze Medikal Park Hospital, iSTANBUL, TURKEY

\begin{abstract}
Objective: Thoracentesis is the first investigation to be performed in a patient with lung cancer and pleural effusion. The diagnostic yield of conventional smear studies varies in the first thoracentesis. In this study, we aimed to investigate if the cell block method increases the diagnostic yield in exudative pleural effusions accompanying lung cancer.
\end{abstract}

Material and Method: Forty patients with lung cancer and exudative pleural effusions were included. Ten mililiters of fresh pleural fluid was obtained by thoracentesis from all patients in the initial evaluation. The pleural fluid sample was divided into two equal parts. One part was subjected to conventional smear and the other to the cell block method. Conventional smears were stained with May-Grünwald-Giemsa and Hematoxylin-Eosin. Cell block sections were stained with Hematoxylin-Eosin and mucicarmine. Conventional smear findings were grouped as "benign cytology" or "malignant cytology". The cell block sections were evaluated for the presence of single tumor cells, acinary or papillary pattern, solid islands and staining with mucicarmine.

Results: There were 20 patients each in the benign and malignant conventional smear group. In the benign group, adding the cell block method to conventional smear provided a diagnosis of malignancy in 4 more patients and the diagnosis of malignant effusion was increased by a ratio of $10 \%(4 / 40)$. In the malignant group, adding the cell block technique provided the subtyping of lung cancer as adenocarcinoma in 7 patients $(7 / 20,35 \%)$.

Conclusion: Our study confirms that the cell block method combined with conventional smear increases the diagnostic yield in exudative pleural effusions accompanying lung cancer.

Key Words: Lung carcinoma, Pleural effusion, Cytology, Cytological Techniques

\section{ÖZ}

Amaç: Torasentez, plevra sıvısı olan akciğer kanserli bir hastada yapılması gereken ilk incelemedir. İlk torasentezde yapılan konvensiyonel sitolojik incelemelerin tanı başarısı değişkendir. $\mathrm{Bu}$ çalışmada, eksudatif plevra sıvısı olan akciğer kanserli hastalarda, hücre bloğu yönteminin tanıyı artırıp artırmağını araştırmayı amaçladık.

Gereç ve Yöntem: Eksudatif plevral sıvısı olan 40 akciğer kanserli hasta çalışmaya alındı. Tanı aşamasında her hastadan torasentezle $10 \mathrm{ml}$ plevra sıvısı alındı. Sıvı iki eşit parçaya ayrıldı. Bir kısım konvansiyonel sitoloji için kullanılırken diğer kısımdan hücre bloğu yapıldı. Konvansiyonel yaymalar May-Grünwald-Giemsa ve Hematoksilen-Eosin ile boyand. Hücre bloğu kesitleri Hematoksilen-Eosin ve musikarmin ile boyandı. Konvansiyonel sitoloji bulguları "benign sitoloji” ve "malign sitoloji” olarak grupland. Sitoblok kesitleri tek tümör hücresi, asiner, papiller patern, solid ada varlığı, musikarmin ile boyanma açısından değerlendirildi.

Bulgular: Benign ve malign konvansiyonel sitoloji grubunun her birinde 20'şer hasta vardı. Benign konvansiyonel sitoloji grubunda, konvensiyonel sitolojiye ek olarak sitoloblok yapılması 4 hastaya daha malignite tanısı konmasını sağlayarak, malign sıvı tanısını (4/40) \%10 oranında artırdı. Konvansiyonel sitolojisi malign olan grupta, sitoblok yönteminin beraber kullanılması, 7 hastada (7/20, \%35) adenokarsinom tanısı koydurarak, akciğer kanserinin subtiplendirmesine olanak sağladı.

Sonuç: Çalışmamız, akciğer kanserine eşlik eden eksudatif plevra sıvisı olan hastalarda, konvansiyonel sitoloji ile birlikte sitoblok yönteminin kullanılmasının tanı değerini artırdığını kanıtlamıştır.

Anahtar Sözcükler: Akciğer kanseri, Plevral effüzyon, Sitoloji, Sitolojik teknikler
(Turk Patoloji Derg 2013, 29:165-170)

Received : 05.06.2013 Accepted : 29.07.2013
Correspondence: Deniz KÖKSAL

Department of Chest Diseases, Atatürk Chest Diseases and Chest Surgery

Training and Research Hospital, ANKARA, TURKEY

E-mail: dckoksal@gmail.com Phone: +90 3125677123 


\section{INTRODUCTION}

Accurate diagnosis and staging of lung cancer is extremely important for proper treatment and predicting prognosis (1). Conforming the nature of a pleural effusion is mandatory in all patients since it influences the disease stage and sometimes confirms the histopathological diagnosis. Thoracentesis should therefore be the first investigation to be performed in a patient with suspected lung cancer. Cytological examination of the pleural fluid is a quick and minimally invasive way to diagnose a malignant effusion (2-4). Many commonly used guidelines recommend cytological analysis of at least two to three samples of pleural effusions. If pleural fluid cytology is negative, imageguided pleural biopsy or medical or surgical thoracoscopy is recommended for the definite diagnosis $(2,5)$.

The accurate identification of cells as either malignant or reactive mesothelial cells is a challenge in conventional smear cytologies (CSS) (6). The cell block (CB) method is one of the oldest methods for evaluation of body cavity fluids. It can be used as adjunct to smears for establishing a more definite cytopathological diagnosis. Its main advantage is the preservation of tissue architecture and obtaining multiple sections for special stains and immunochemistry (7-9). However it is not used widely in routine daily clinical practice. Nevertheless it is a simple method requiring no special training or instrument. It is safe, cost-effective and reproducible even in resource-limited rural areas (10). In this small study, we aimed to investigate if the CB method increases the diagnostic yield in exudative pleural effusions accompanying lung cancer.

\section{MATERIAL and METHODS}

\section{Patients}

Forty patients with lung cancer (28 males/ 12 females, mean age: $64 \pm 12$ years) with exudative pleural effusions who were diagnosed and treated in our clinic during a oneyear period (January-December 2011) were included in this study (Table I). The study was approved by our institutional local ethics committee.

All of the study subjectswere primarylung cancercases whose diagnoses were confirmed with pathological or cytological examinations supported by immunohistochemical studies. The diagnosis was made by fiberoptic bronchoscopic biopsy in 16 , pleural fluid cytology in 7 , computed tomography guided transthoracic biopsy in 5, video-assisted thoracic surgery pleural biopsy in 4, closed pleural biopsy in 3, scalene lymph node biopsy in 4 patients, and endobronchial ultrasonography guided mediastinal lymph node biopsy in
1 patient. The histological diagnosis was adenocarcinoma in 22 , squamous cell carcinoma in 8 , non-small cell carcinoma in 2, small cell carcinoma in 3, and malignant epithelial tumor (MET) in 5 patients.

\section{Conventional smear cytology (CSS) and cell block (CB) method}

Ten mililiters of fresh pleural fluid sample was obtained by thoracentesis in all patients during the initial evaluation. The pleural fluid sample was divided into two equal parts of five mililiters each. One part was subjected to CSS. The sample was centrifuged at $3000 \mathrm{rpm}$ for 3 minutes. Two thin smears were prepared from the sediment and stained with May-Grünwald-Giemsa stain and Hematoxylin-Eosin. The other part was also centrifuged at $3000 \mathrm{rpm}$ for 3 minutes for the CB method. A mixture of equal amounts of $98 \%$ ethyl-alcohol and 10\% buffered formalin was added on the sediment and after one hour it was routinely processed to paraffin wax. Paraffin embedded CB sections of $6 \mu \mathrm{m}$ thickness were prepared. Three $\mathrm{CB}$ sections were stained with Hematoxylin-Eosin and one with the special stain mucicarmine.

CSS findings were grouped as "benign cytology" or "malignant cytology". The "suspicion of malignancy" was grouped in the "benign cytology" group. The CB sections were evaluated for the presence of single tumor cell, acinary, papillary pattern, solid islands and staining with mucicarmine. A demonstration of papillary and acinary pattern and mucin positivity on $\mathrm{CB}$ sections are seen in Figure 1, 2 respectively.

\section{Statistical analysis}

The SPSS for windows release 19.0 package program was used to carry out descriptive statistical analysis. The descriptive analysis was expressed in terms of frequency, mean and standart deviation.

\section{RESULTS}

The CSS and CB findings of the study patients are presented in Table II. The CSS findings were benign in 17 (42.5\%), suspicion of malignancy in 3 (7.5\%), malignant epithelial tumor in $13(32.5 \%)$ and adenocarcinoma in 7 (17.5\%) patients. When the study patients were grouped as benign or malignant CSS group, there were 20 patients in each.

In the benign CSS group, the CB method diagnosed 4 more patients as malignant effusion. CSS findings were suspicion of malignancy in three and benign cytology in one of these patients. The diagnosis of malignant effusion was increased by a ratio of (4/40) 10\%. In 3 of these 4 
patients the histological diagnosis of adenocarcinoma were also confirmed by demonstrating acinary and/or papillary pattern and positive staining with mucicarmine in $\mathrm{CB}$ sections. The CB findings of these 4 patients are presented in Table III.

In the malignant CSS group, CSS diagnoses were MET in 13 (32.5\%), adenocarcinoma in 7 (17.5\%) patients. In 4 patients we could not obtain a tissue for CB sections. In 9 patients CSS and CB diagnoses were concordant. In 7 patients who were diagnosed as MET by CSS, the CB method provided the subtyping as adenocarcinoma. Overall, adding the $\mathrm{CB}$

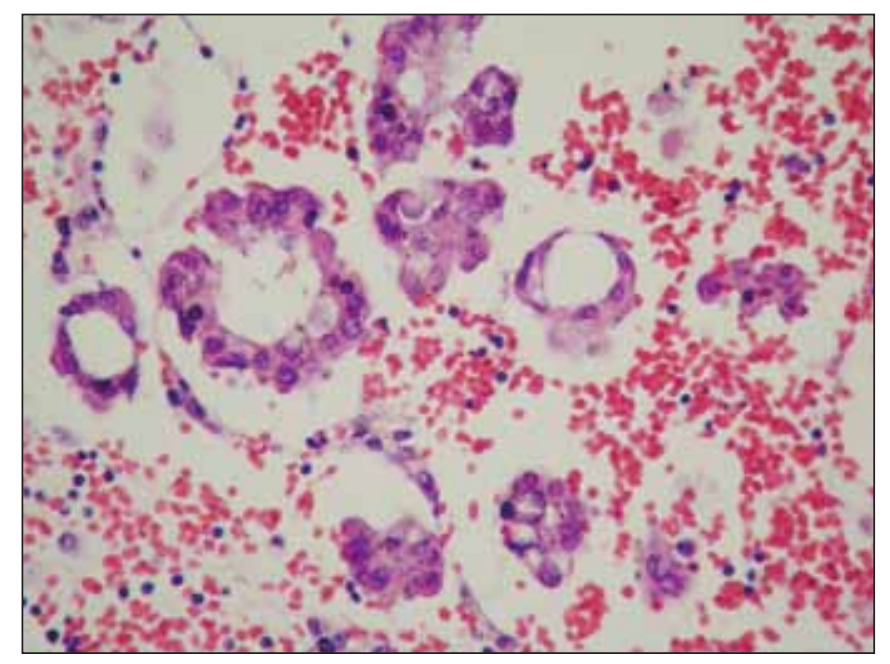

Figure 1: Papillary and acinary pattern on a cell block section (HEx400). method to CSS increased the histological diagnosis by $35 \%$ (7/20).

\section{DISCUSSION}

Thoracentesis is the first investigation to be performed in a patient with suspected lung cancer and pleural effusion. The differentiation of a malignant effusion from a paramalignant effusion is extremely important since it alters the disease stage and treatment of the particular patient (2). The majority of effusions are due to direct carcinomatous involvement of the pleura. Pleural metastases are more

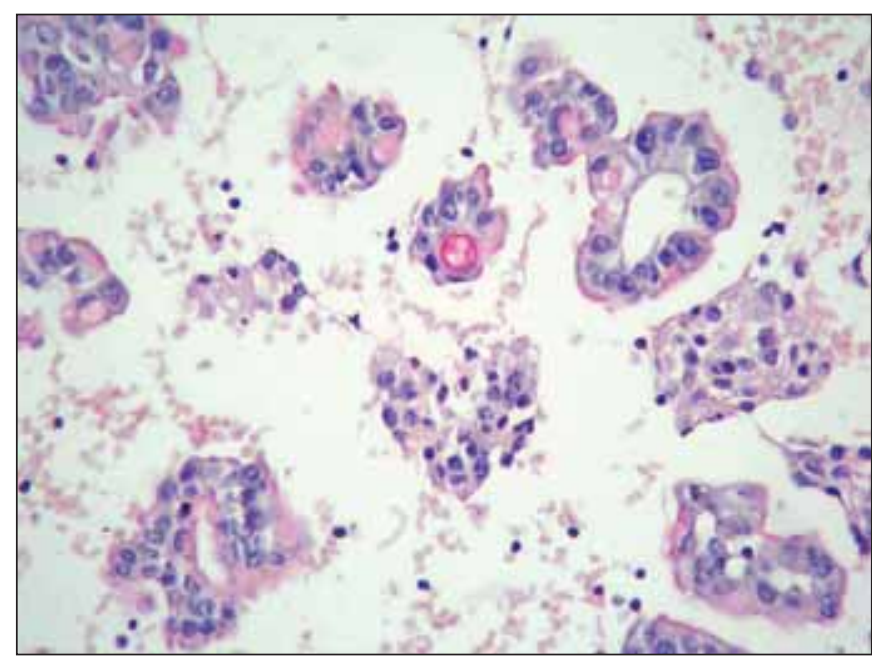

Figure 2: Mucin positivity in tumor cells on a cell block section (Mucicarminex400).

Table I: The characteristics of study patients

\begin{tabular}{|l|l|c|}
\hline Number of patients & 40 & \multicolumn{2}{|l|}{} \\
\hline Male/ Female & $28 / 12$ & 16 \\
\hline Mean age (years) & $64 \pm 12$ years (min-max: 29-91) & 7 \\
\hline \multirow{5}{*}{ The way of diagnosis } & Fiberoptic bronchoscopic biopsy & 5 \\
\cline { 2 - 3 } & Pleural fluid cytology & 4 \\
\cline { 2 - 3 } & CT guided transthoracic biopsy & 3 \\
\cline { 2 - 3 } & VATS pleural biopsy & 4 \\
\cline { 2 - 3 } & Closed pleural biopsy & 1 \\
\cline { 2 - 3 } & Scalen lymph node biopsy & 22 \\
\cline { 2 - 3 } & EBUS guided mediastinal lymph node biopsy & 8 \\
\hline & Adenocarcinoma & 2 \\
\cline { 2 - 3 } & Squamous cell carcinoma & 3 \\
\cline { 2 - 3 } & Non-small cell carcinoma & 5 \\
\cline { 2 - 3 } & Small cell carcinoma & \\
\cline { 2 - 3 } & Malignant epithelial tumor & \\
\hline
\end{tabular}

CT: Computed tomography, VATS: Video assisted thoracic surgery, EBUS: Endobronchial ultrasonography. 
common in the visceral pleura and tend to be focal in the parietal pleura (11). That's why pleural fluid cytology is a more sensitive diagnostic test than closed percutaneous pleural biopsy $(12,13)$. Series examining the diagnostic rate of pleural cytology for malignancy have reported a mean sensitivity of about $60 \%$ ranging between $40-87 \%$ (13-16). The yield from sending more than two samples taken on different occasions is low. In a study, the diagnostic yield was found to be $65 \%$ for the first specimen, a further $27 \%$ for the second specimen and only $5 \%$ for the third (16).

Commonly used guidelines such as ACCP (American College of Chest Physicians) (2) and NCCN (National Comprehensive Cancer Network) (5) recommend medical or surgical thoracoscopy as the next step after at least two negative thoracenteses. Thoracoscopic pleural biopsy

Table II: The conventional smear cytology and cell block findings of study patients

\begin{tabular}{|c|c|c|c|c|c|}
\hline \multicolumn{3}{|c|}{ Benign CSS group } & \multicolumn{3}{|c|}{ Malignant CSS group } \\
\hline Case & CSS & $\mathrm{CB}$ & Case & CSS & CB \\
\hline 1 & Benign & Benign & 1 & MET & $\Phi$ \\
\hline 2 & Benign & Benign & 29 & MET & Adenocarcinoma \\
\hline 3 & Benign & Benign & 3 & Adenocarcinoma & Adenocarcinoma \\
\hline $4^{*}$ & Suspicion of maligancy & Adenocarcinoma & 4 & MET & MET \\
\hline 5 & Benign & Benign & $5 g$ & MET & Adenocarcinoma \\
\hline $6^{*}$ & Suspicion of malignancy & Adenocarcinoma & 6 & MET & MET \\
\hline 7 & Benign & Benign & 79 & MET & Adenocarcinoma \\
\hline 8 & Benign & Benign & 8 & MET & MET \\
\hline 9 & Benign & Benign & 9 & MET & $\Phi$ \\
\hline 10 & Benign & Benign & 10 & MET & $\Phi$ \\
\hline 11 & Benign & Benign & 11 & Adenocarcinoma & $\Phi$ \\
\hline $12^{\star}$ & Suspicion of malignancy & Adenocarcinoma & 12 & Adenocarcinoma & Adenocarcinoma \\
\hline 13 & Benign & Benign & 13 & Adenocarcinoma & Adenocarcinoma \\
\hline 14 & Benign & Benign & 14 & Adenocarcinoma & Adenocarcinoma \\
\hline 15 & Benign & Benign & $15 \mathrm{~g}$ & MET & Adenocarcinoma \\
\hline 16 & Benign & Benign & 169 & MET & Adenocarcinoma \\
\hline 17 & Benign & Benign & 17 & Adenocarcinoma & Adenocarcinoma \\
\hline 18 & Benign & Benign & $18 \mathrm{~g}$ & MET & Adenocarcinoma \\
\hline $19^{*}$ & Benign & MET & $19 \mathrm{~g}$ & MET & Adenocarcinoma \\
\hline 20 & Benign & Benign & 20 & Adenocarcinoma & Adenocarcinoma \\
\hline
\end{tabular}

CSS: Conventional Smear Cytology, CB: Cell Block, MET: Malignant Epithelial Tumor.

${ }^{*}$ By adding CB method to CSS, 4 more patients were also diagnosed as malignant. The diagnosis of malignant effusion was increased by a ratio of (4/40) $10 \%$.

$\Phi$ In 4 patients we could not obtain a tissue for CB sections.

In 7 patients (35\%) diagnosed as MET by CSS, CB method provided the subtyping as adenocarcinoma.

Table III: The histological findings of four patients diagnosed as malignant by cell block method

\begin{tabular}{|c|l|c|c|c|c|c|c|}
\hline Case & CSS & $\begin{array}{c}\text { Single } \\
\text { tumor cell }\end{array}$ & $\begin{array}{c}\text { Acinary } \\
\text { pattern }\end{array}$ & $\begin{array}{c}\text { Papillary } \\
\text { pattern }\end{array}$ & $\begin{array}{c}\text { Solid } \\
\text { island }\end{array}$ & Mucicarmine & CB \\
\hline 1 & Suspicion of malignancy & + & - & - & - & + & Adenocarcinoma \\
\hline 2 & Suspicion of malignancy & + & - & + & - & + & Adenocarcinoma \\
\hline 3 & Suspicion of malignancy & - & + & + & - & + & Adenocarcinoma \\
\hline 4 & Benign cytology & + & - & - & + & - & MET \\
\hline
\end{tabular}

CSS: Conventional Smear Cytology, CB: Cell Block, MET: Malignant Epithelial Tumor. 
can provide a definitive diagnosis with a high degree of accuracy (17). It also has some additional advantages such as permitting the evaluation of chest wall invasion, mediastinal invasion, or malignant mediastinal lymph node involvement. However, it is an invasive procedure for a patient with probable advanced stage lung carcinoma.

Recently published BTS (British Thoracic Society) pleural disease guideline mentions that diagnostic yield of more than two pleural effusion specimens taken on different occasions is very low and should be avoided. It also mentions that the yield for malignancy increases if both cell blocks and smears are prepared from pleural fluid samples (18).

CSS is a widely used simple procedure for cytological diagnosis of malignancy in pleural effusions with a sensitivity of $40-70 \%$. The major challenge is the difficulty of distinguishing reactive mesothelial cells from malignant ones (19). This may be due to marked atypia of mesothelial cells caused by chemical, physical, immunological and metabolic stimuli on the pleural membrane or subtle cytomorphological features of some malignancies such as well-differentiated adenocarcinomas. Artifacts from poor fixation, preparation, or staining techniques may contribute to this difficulty (20). Although the preparation of CSS is a simpler procedure than paraffin sections, it has the limitation of a lack of tissue architecture (21). Overcrowding of cells, abundance of inflammatory cells, paucity of representative cells or cell loss due to different laboratory processing methods contribute to considerable difficulties in making a definite diagnosis of malignancy (22).

CB procedures have now become an established part of cytological diagnosis. They have the advantage of recognition of histological patterns of diseases, possibility to study multiple sections by routine staining, special staining and immunocytological procedures. They have less cellular dispersal that permits easier microscopic observation than do CSS. Cell blocks provide better milieu for morphologic interpretation, with less background staining (23). Apart from increased cellularity, better morphological details such as cell balls, papillae, three-dimensional clusters, better nuclear and cytoplasmic preservation, intact cell membrane and crisp chromatin details (6). They give the possibility of unlimited storage and molecular testing similar to histological samples (6-8). Immunohistochemical studies (MOC-31, D2-40, calretinin) performed on cell blocks were found to be useful in the differentiation between adenocarcinomas and reactive mesothelial cells (10). In the study of Shivakumarswamy et al, the CB method increased the diagnostic yield for malignancy by $15 \%$ (6). Ghosh et al included a total of 60 cases with suspected malignant pleural effusion in their study. The CB method diagnosed 46 cases of the 56 patients who were confirmed to be malignant by all other modalities. They concluded that $\mathrm{CB}$ method has an effective role in definitive diagnosis (24). Liao et al studied glucose transporter 1(GLUT 1) expression, which is a hallmark metabolic change in cancer cells, using immunocytochemistry on cell blocks in benign, atypical, or malignant pleural effusions. They determined that malignant effusion cell blocks were positive for GLUT 1 expression in $84.4 \%$ of cases with a $100 \%$ specificity and 93.2\% accuracy (25). Khoor et al evaluated the expression of TTF-1 on cell blocks in malignant pleural effusions, 26 pulmonary adenocarcinomas, 26 non-pulmonary adenocarcinomas and 4 malignant mesotheliomas. They have shown that while nuclear immunoreactivity for TTF-1 was detected in 19 pulmonary adenocarcinomas, all nonpulmonary adenocarcinomas and malignant mesotheliomas were negative. They concluded that TTF-1 expression in cell block preparations is useful in differentiation of pulmonary adenocarcinomas from non-pulmonary adenocarcinomas and malignant mesothelioma (26). In the present study, despite a small study group, we showed that the diagnosis of a malignant pleural effusion is inceased by (4/40) $10 \%$ by adding CB method to CSS.

The histological subtype of lung cancer is becoming increasingly important in selecting a proper chemotherapy agent (27). In this study we used the mucicarmine stain and determined that adding the $\mathrm{CB}$ method and staining with mucicarmine provided the subtyping of lung cancer as adenocarcinoma in 7 patients $(7 / 20,35 \%)$ in the malignant CSS group.

Despite these advantages, many clinicians do not request the $\mathrm{CB}$ method combined with CSS in routine daily clinical practice. In our institute, clinicians have to request the $\mathrm{CB}$ method from the pathologist. Since there are too many pleural effusions sent for cytological diagnosis, it is difficult and not cost-effective to prepare cell blocks for all of the pleural effusion samples (28). That's why we think that clinicians should alert the pathologist in patients with suspected malignant pleural effusion.

In the earlier years, the $\mathrm{CB}$ method did not receive much attention probably due to the lack of a standardized technique. Since some researchers used agar, plasma/ thromboplastin to bind the sedimented cells, another limitation was the risk of losing material during preparation $(6,21,22)$. In this study, we used alcohol-formalin as a fixative in order to get a better cellularity in CB sections. We know that formalin forms crosslinks and gel formation that 
could not be dissolved by various chemicals used during processing and by that way minimizes cell loss. However, we could not obtain tissue by the $\mathrm{CB}$ technique in 4 patients who were diagnosed as malignant by CSS. The common characteristic of these 4 patients was low cellularity on CSS.

In conclusion, our study confirms that the $\mathrm{CB}$ method combined with CSS increases the diagnostic yield in exudative pleural effusions accompanying lung cancer. The CB method should therefore be considered as a useful adjuvant technique along with CSS in evaluating pleural fluid cytology for increased cytodiagnosis.

\section{REFERENCES}

1. Goldstraw P, (ed): International Association for the Study of Lung Cancer Staging Manual in Thoracic Oncology. 1st ed. Orange Park, FL: Editorial Rx Press, 2009

2. Rivera MP, Mehta AC, Wahidi MM: Establishing the diagnosis of lung cancer. Diagnosis and Management of Lung Cancer, $3^{\text {rd }}$ ed: ACCP Evidence-Based Clinical Practice Guidelines. Chest 2013, 143(5)(Suppl): e142S-e165S

3. Dağlı AF, Küçük Ş, Sezer M, Üçer Ö: Cytopathologic diagnosis in pleural effusion and cyto-histopathologic correlation. Turkish J Pathol 2011, 27:12-16

4. Gupta S, Sodhani P, Jain S: Cytomorphological profile of neoplastic effusions: An audit of 10 years with emphasis on uncommonly encountered malignancies. J Cancer Res Ther 2012, 8:602-609

5. NCCN Clinical Practice Guidelines in Oncology, Non-small Cell Lung Cancer, Version 3. 2012

6. Shivakumarswamy U, Arakeri SU, Karigowdar MH, Yelikar BR: Diagnostic utility of the cell block method versus the conventional smear study in the pleural fluid cytology. J Cytol 2012, 29:11-15

7. Nathan NA, Narayan E, Smith MM, Horn MJ: Cytologyimproved preparation and its efficacy in diagnostic cytology. Am J Clin Pathol 2000, 114:599-606

8. Kuhlmann L, Berghauser KH, Schaffer R: Distinction of mesothelioma from carcinoma in pleural effusions. An immunocytochemical study on routinely processed cytoblock preparations. Pathol Res Pract 1991, 187:467-471.

9. Jing X, Li QK, Bedrossian U, Michael CW: Morphologic and immunocytochemical performance of effusion cell blocks prepared using 3 different methods. Am J Clin Pathol 2013, 139:177-182

10. Kim JH, Kim GE, Choi YD, Lee JS, Lee JH, Nam JH, Choi C: Immunocytochemical panel for distinguishing between adenocarcinomas and reactive mesothelial cells in effusion cell blocks. Diagn Cytopathol 2009, 37:258-261

11. Rodriguez-Panadero F, Bordens Naranjo F, Lopez-Mejias $J$ : Pleural metastatic tumors and effusions. Frequency and pathogenic mechanisms in a post-mortem series. Eur Respir J 1989, 2:366-369

12. Johnston WW: The malignant pleural effusion: A review of cytopathologic diagnoses of 584 specimens for 472 consecutive patients. Cancer 1985, 56:905-909
13. Prakash UBS, Reinman HM: Comparison of needle biopsy with cytologic analysis for THA evaluation of pleural effusion: Analysis of 414 cases. Mayo Clin Proc 1985, 60:158-64

14. Salyer WR, Eggleston JC, Erozan YS: Efficacy of pleural needle biopsy and pleural fluid cytopathology in the diagnosis of malignant neoplasm involving the pleura. Chest 1975, 67: 536-539

15. Nance KV, Shermer RW, Askin FB: Diagnostic efficacy of pleural biopsy as compared with that of pleural fluid examination. Mod Pathol 1991, 4:320-324

16. Garcia $L$ : The value of multiple fluid specimens in the cytological diqgnosis of malignancy. Mod Pathol 1994, 7:665-668

17. Rusch VW, Mountain C: Thoracoscopy under regional anesthesia for the diagnosis and management of pleural disease. Am J Surg 1987, 154:274-278

18. Hooper C, Lee YCG, Maskell N: On behalf of the BTS Pleural Guideline Group. Investigation of unilateral pleural effusion in adults: BTS pleural disease guideline 2010. Thorax 2010, 65(suppl 2):ii4-ii17

19. Bousfield LR, Greenberg ML, Pacey F: Cytogenetic diagnosis of cancer from body fluids. Acta Cytol 1985, 29:768-773

20. Price BA, Ehya H, Lee JH: Significance of pericellular lacunae in cell blocks of effusions. Acta Cytol 1992, 36:333-337

21. Kung IT, Yuen RW, Chan JK: Technical notes. Optimal formalin fixation and processing schedule of cell blocks from the fine needle aspirates. Pathology 1989, 21:143-145

22. MezgerJ, Stotzer O, Schilli G, BauerS, Wilmanns W:Identification of carcinoma cells in ascitic and pleural fluid. Comparison of four panepithelial antigens with carcinoembryonic antigen. Acta Cytol 1992, 36:75-81

23. Fetsch PA, Simsir A, Brosky K, Abati A: Comparison of three commonly used cytologic preparations in effusion immunochemistry. Diagn Cytopathol 2002, 26:61-66

24. Ghosh I, Dey SK, Das A, Bhattacharjee D, Gangopadhyay S: Cell block cytology in pleural effusion. J Indian Med Asoc 2012, 110:390-392, 396

25. Liao ND, Chiang TA, Lee WY: Glucose transporter 1 protein detected by enzyme-linked immunosorbent assay and immunocytochemistry: A useful diagnostic tool for malignant pleural effusions. Cancer Cytopathol 2013 Jul 16. doi: 10.1002/ cncy.21324 [Epub ahead of print]

26. Khoor A, Byrd-Gloster AL, Nicosia SV: Expression of thyroid transcription factor-1 in malignant pleural effusions. Pathol Oncol Res 2011, 17:263-267

27. Scagliotti G, Brodowicz T, Shepherd FA, Zielinski C, Vansteenkiste J, Manegold C, Simms L, Fossella F, Sugarman K, Belani CP: Treatment-by-histology interaction analyses in three phase III trials show superiority of pemetrexed in nonsquamous non-small cell lung cancer. J Thorac Oncol 2011, 6:64-70

28. Jonasson JG, Ducatman BS, Wang HH: The cell block for body cavity fluids: Do the results justify the cost? Mod Pathol 1990, 3:667-670 